\title{
Kinetics and Mechanism of Nucleophilic Displacement Reactions of Y-Substituted Phenyl Benzoates with Z-Substituted Phenoxides
}

\author{
Se-Won Min, Jin-A Seo, and Ik-Hwan Um \\ Department of Chemistry and Nano Science, Ewha Homans Cniversity, Seoul 120-750, Korea \\ ${ }^{*}$ E-mail: ihtmatewhac. $\mathrm{kr}$ \\ Received August 6. 2009. Accepted September +. 2009
}

\begin{abstract}
Second-order rate constants have been measured for two series of nucleophilic displacement reactions, i.e., reactions of 4-nitrophenyl benzoate with Z-substituted phenoxides and those of Y-substituted phenyl benzoates (1a-h) with 4-chlorophenoxide (4-ClPhO') in $80 \mathrm{~mol}^{\circ} \mathrm{H}_{2} \mathrm{O} / 20 \mathrm{~mol} \% \mathrm{DMSO}$ at $25.0 \pm 0.1^{\circ} \mathrm{C}$. The Bronsted-type plot for reactions of 4-nitrophenyl benzoate with Z-substituted phenoxides exhibits an excellent linear correlation with $\beta_{\text {nuc }}=0.72$. Reactions of 1a-h with 4-chlorophenoxide result in also a linear Bronsted-ty pe plot with $\beta_{\text {lg }}=-0.62$, a typical $\beta_{\mathrm{lg}}$ value for a concerted mechanism. The Hanmett plots correlated with $\sigma^{\circ}$ and $\sigma^{-}$constants show many scattered points for reactions of $\mathbf{1 a - h}$ with 4 -chlorophenoxide. In contrast, the corresponding Yukawa-Tsuno plot exhibits an excellent linear conelation with $\mathrm{pr}_{\mathrm{r}}=2.26$ and $r=0.53$, indicating that expulsion of the leaving group occurs at the rate-determining step (RDS) either in a concerted mechanism or in a stepwise pathway. However, a stepwise mechanism with leaving group departure being the RDS is excluded since the leaving Y-substituted phenoxide is less basic and a better nucleofuge than the incoming 4-CIPhO'. Thus, the reactions have been concluded to proceed through a concerted mechanism, in which bond formation between the nucleophile and electrophilic center is more advanced than expulsion of the leaving group in the transition state on the basis of the magnitude of $\beta_{\text {muc }}$ and $\beta_{\text {lg }}$ values.
\end{abstract}

Key Words: Acyl-group transfer. Arỵl berzoates. Bronsted-type plot. Concerted meclanișm. Yukawa-Tșu plot

\section{Introduction}

Acyl-group transfer reactions have been reported to proceed through a concerted mechanism or through a stepwise mechanism depending on reaction conditions. ".5 Aminolysis of aryl acetates and benzoates have generally been understood to proceed through a stepwise mechanism with a change in rate-determining step (RDS) on the basis of curved Bronstedtype plots found for reactions of esters with a good leaving group (e.g., 2.4-dinitrophenoxide) ${ }^{1.5}$ RDS has been suggested to change at $\mathrm{p} K_{\mathrm{a}}^{\circ}$ defined as the curvature center of a curved Bronsted-type plot. i.e., RDS changes from breakdown of the intermediate to its formation as the incoming amine becomes more basic than the leaving ary loxide by + to $5 \mathrm{pKa}_{\mathrm{a}}$ units. ${ }^{1-5}$

However. reactions with anionic nucleophiles have not been completely understood. Williams et al. have concluded that reactions of 4-nitrophenyl acetate with a series of substituted phenoxides. whose basicity straddles the leaving 4-nitrophenoxide. proceed through a concerted mechanism on the basis of a linear Bronsted-type plot. ${ }^{6}$ This is because a curved Bronsted-type plot would be expected if the reaction proceeds through a stepwise mechanism. ${ }^{6}$ In contrast. it has been reported that reactions of substituted phenyl acetates with phenoxide proceed through an addition intermediate with its formation being RDS. The evidence provided was that $\sigma^{-}$constants result in a poorer Hammett correlation than $\sigma^{\circ}$ constants.

We have recently shown that deduction of reaction mechanism based just on Hammett correlations with $\sigma^{-}$or $\sigma^{\circ}$ constants might be misleading for alkaline hỵdroly'sis and ethanoly'sis of Y-substituted phenỵl diphenỵlphosphinates and related com-

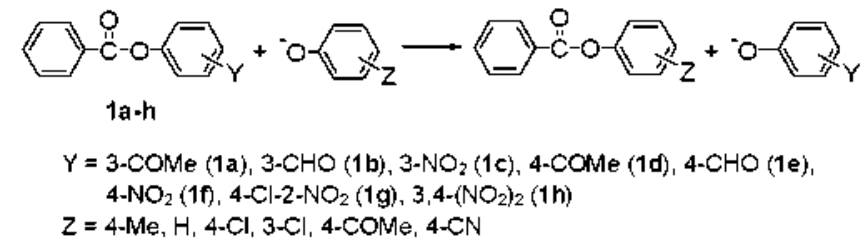

Scheme 1

pounds. ${ }^{3}$ It was found that $\sigma^{\circ}$ constants result in better Hammett correlation than $\sigma^{-}$constants. Traditionally, such a result was taken as evidence for a stepwise mechanisn. ${ }^{9 \cdot 13}$ However. we concluded that the reactions proceed through a concerted mechanism since the corresponding Yukawa-Tsuno plot resulted in an excellent linear correlation. ${ }^{3.14}$

To get more information on mechanism for acyl-group transfer reactions, our study has been extended to reactions of 4-nitropheryl benzoate with a series of Z-substituted phenoxides and those of Y-substituted phenyl berzoates (1a-h) with 4-chlorophenoxide (Scheme 1). We have concluded that the reactions proceed through a concerted mechanism on the basis of LFERs (e.g., Bronsted-type plots, Hanmett plots. and Yukawa-Tsuno plots).

\section{Results and Discussion}

The kinetic study was performed under pseudo-first-order conditions with the concentration of nucleophile in excess over the substrate concentration. All reactions obeyed first-order kinetics with quantitative liberation of Y-substituted pheno.ide ion. Pseudo-first-order rate constants $\left(k_{\text {otsd }}\right)$ were calculated 
Table 1. Summary of Second-order Rate Constants ( $k z$-eho-) for Reactions of 4-Nitropheny 1 Benzoate with Z-Substituted Phenoxides $\left(\mathrm{Z}-\mathrm{C}_{6} \mathrm{H}_{+} \mathrm{O}^{-}\right.$) in $80 \mathrm{~mol} \% \mathrm{H}_{2} \mathrm{O} / 20 \mathrm{~mol} \%$ DMSO at $25.0 \pm 0.1{ }^{\circ} \mathrm{C}$.

\begin{tabular}{clcc}
\hline Entry & \multicolumn{1}{c}{$Z$} & $\mathrm{pK}_{\mathrm{a}}{ }^{\mathrm{Z} \cdot \mathrm{C}_{\mathrm{e}} \mathrm{H}_{4} \mathrm{OH}}$ & $10^{3} \mathrm{kz} \cdot \mathrm{PhlO}-/ \mathrm{M}^{-1} \mathrm{~s}^{-1}$ \\
\hline 1 & $4-\mathrm{Me}$ & $11.7^{a}$ & 925 \\
2 & $\mathrm{H}$ & $11.3^{a}$ & 452 \\
3 & $4-\mathrm{Cl}$ & $10.5^{a}$ & 185 \\
4 & $3-\mathrm{Cl}$ & $10.2^{b}$ & 90.3 \\
5 & $4-\mathrm{COMe}$ & $8.94^{b}$ & 8.88 \\
6 & $4-\mathrm{CN}$ & $8.60^{a}$ & 5.10 \\
\hline
\end{tabular}

${ }^{a} K_{\mathrm{a}}$ in 20 mol". DMSO taken from ref. 7(a). ${ }^{\mathrm{p}} \mathrm{K}_{\mathrm{a}}$ in 20 mol".0 DMSO

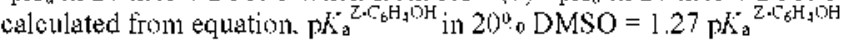
in $\mathrm{H}_{2} \mathrm{O}-1.28$

from the equation $\ln \left(A x_{-}-A_{\mathrm{t}}\right)=-k_{\text {obsd }} t+C$. The plots of $k_{\mathrm{sbad}}$ vs. nucleophile concentration were linear. Second-order rate constants were determined from the slope of the linear plots and summarized in Tables 1 and 2. It is estimated from replicate runs that the uncertainty in the rate constants is less than $\pm 3 \%$.

Effect of Basicity of Incoming Ayloxides on Reactivity. As shown in Table 1 , the second-order rate constant ( $k$-Pyn:- $)$ for reactions of +-nitrophenyl benzoate with $Z$-substituted phenoxide $\left(\mathrm{Z}-\mathrm{C}_{6} \mathrm{H}_{4} \mathrm{O}^{-}\right)$decreases as the basicity of incoming aryloxide decreases. e.g. it decreases from $0.925 \mathrm{M}^{-1} \mathrm{~s}^{-1}$ to 0.185 and $5.10 \times 10^{-3} \mathrm{M}^{-1} \mathrm{~s}^{-1}$ as the $\mathrm{p} K_{\mathrm{a}}$ of the conjugate acid of the ary loxide decreases from 11.7 to 10.5 and 8.6. in turn. The effect of basicity of aryloxides on reactivity is illustrated in Figure 1. The Bronsted-type plot exhibits an excellent linear correlation with $\beta_{\text {uuc }}=0.72$.

The magnitude of $\beta_{\text {uuc }}$ values has generally been understood to represent a relative degree of bond fomation in the transition state. ${ }^{15.16}$ Accordingly $\beta_{\text {nuc }}$ has been taken as a measure of reaction mechanism. e.g., $\beta_{\mathrm{tmc}}=0.5 \pm 0.1$ for reactions

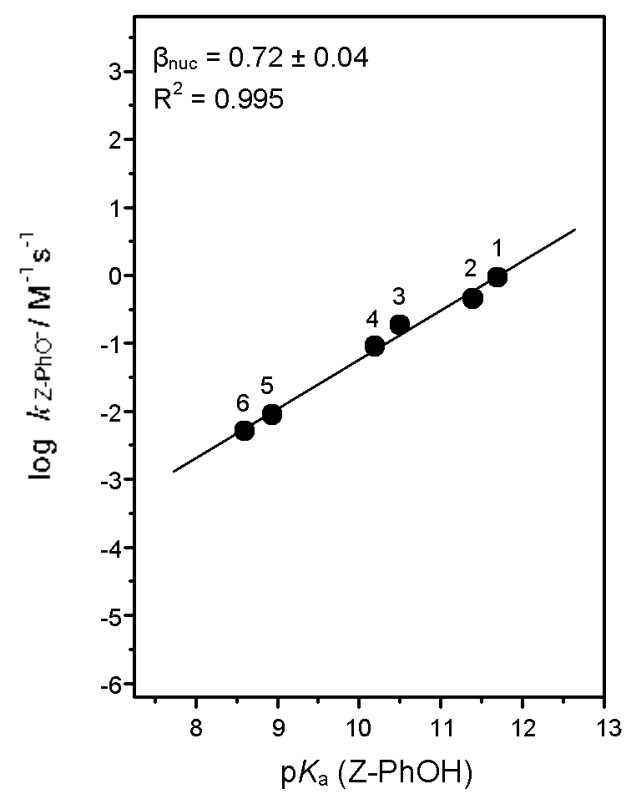

Figure 1. Bronsted-type plot for reactions of 4 -nitrophenyl benzoate

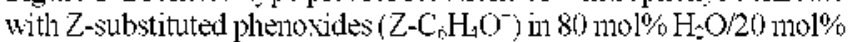
DMSO at $25.0 \pm 0.1{ }^{\circ} \mathrm{C}$. The identity of points is given in Table 1. proceeding through a concerted mechanism while $\beta_{\text {nuc }}=0.2 \pm$ 0.1 or $0.9 \pm 0.2$ for those reported to proceed through a stepwise mechanism depending on the rate-determining step (RDS) ${ }^{15.16}$ The current $\beta_{134}$ value of 0.72 inplies that the degree of bond formation in the transition state is relatively high. Thus, one nught suggest that the current reaction proceeds through intermediate 2 . in which expulsion of 4-nitrophenoxide from 2 occurs in the $\mathrm{RDS}$ on the basis of the $\beta_{\text {nuc }}$ value.

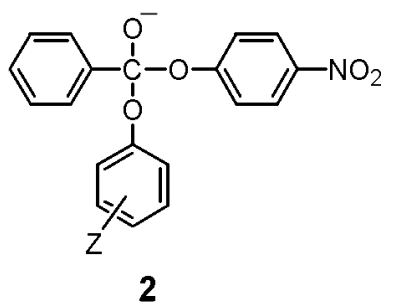

The RDS for a stepwise mechanism would be determined by the basicity of nucleofuges. e.g., t-nitrophenoxide and Z-substituted phenoxide in this study. One might expect that 4-nitrophenoxide would depart more rapidly than Z-substituted phenoxide. since the former is less basic and a better nucleofuge than the latter. Accordingly. expulsion of 4-nitrophenoxide from 2 is expected to occur after the RDS. Thus, one can suggest that the current reaction proceeds through a concerted mechanism and the $\beta_{m u c}$ value of 0.72 found in this study would be an upper limit for a concerted mechanism (i.e.. a large bond formation in the transition state).

Effect of Leaving-Group Basicity on Reactivity. To examine the above argument. second-order rate constants ( $\left.k_{4 \cdot c[\mathrm{~F}] \mathrm{C}_{-}^{-}}\right)$ have been measured for reactions of Y-substituted phenyl benzoates (1a-h) with 4-chlorophenoxide $\left(4-\mathrm{ClPhO}^{-}\right)$. As shown in Table 2. $k_{4-C p h-}$ increases as the leaving ary loxide becomes less basic. e.g. it increases from $3.45 \times 10^{-3} \mathrm{M}^{-1} \mathrm{~s}^{-1}$ to $5.52 \times 10^{-2}$ and $7.19 \mathrm{M}^{-1} \mathrm{~s}^{-1}$ as the $\mathrm{p} K_{\mathrm{a}}$ of the conjugate acid of the leaving ary loxide decreases from 10.4 to 8.45 and 5.60 . in turn.

The effect of leaving group basicity on reactivity is illustrated in Figure 2 . The Bronsted-type plot is linear with $\beta_{\mathrm{gg}}=-0.62$. which is a typical $\beta_{\mathrm{g}}$ value for reactions reported to proceed

Table 2. Summary of Second-order Rate Constants for Reactions of Y-Substituted Phenyl Benzoates (1a-h) with 4-Chlorophenoxide (4-ClPhO $)$ in $80 \mathrm{~mol}^{-} \mathrm{H}_{2} \mathrm{O} / 20 \mathrm{~mol} \%$ DMSO at $25.0 \pm 0.1^{\circ} \mathrm{C}$.

\begin{tabular}{|c|c|c|c|}
\hline & Y & $p K_{a}^{\gamma^{Y}-\mathrm{PhOH}}$ & $k_{1} \cdot \mathrm{ClPh}^{\prime C^{-}} / \mathrm{M}^{1} \mathrm{~s}^{-1}$ \\
\hline $1 \mathbf{a}$ & $3-\mathrm{COCH}_{3}$ & 10.4 & $3.45 \times 10^{-3}$ \\
\hline 1b & $3-\mathrm{CHO}$ & 10.1 & $6.10 \times 10^{3}$ \\
\hline 1c & $3-\mathrm{NO}_{2}$ & 9.32 & $4.16 \times 10^{-2}$ \\
\hline ld & $4-\mathrm{COCH}_{3}$ & 8.94 & $2.36 \times 10^{\circ}=$ \\
\hline le & $4-\mathrm{CHO}$ & 8.45 & $5.52 \times 10^{-2}$ \\
\hline If & $4-\mathrm{NO}_{2}$ & 7.79 & $1.85 \times 10^{.1}$ \\
\hline $1 \mathrm{~g}$ & $4-\mathrm{Cl}-2-\mathrm{NO}_{2}$ & 6.92 & $2.15 \times 10^{.1}$ \\
\hline $\mathrm{lh}$ & $3,4-\left(\mathrm{NO}_{2}\right)_{2}$ & 5.60 & 7.19 \\
\hline
\end{tabular}

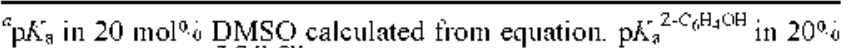
$\mathrm{DMSO}=1.27 \mathrm{pH}_{\mathrm{a}}^{\mathrm{Z} \cdot \mathrm{C}_{6} \mathrm{H}_{4} \mathrm{OH}}$ in $\mathrm{H}_{2} \mathrm{O}-1.28$ 


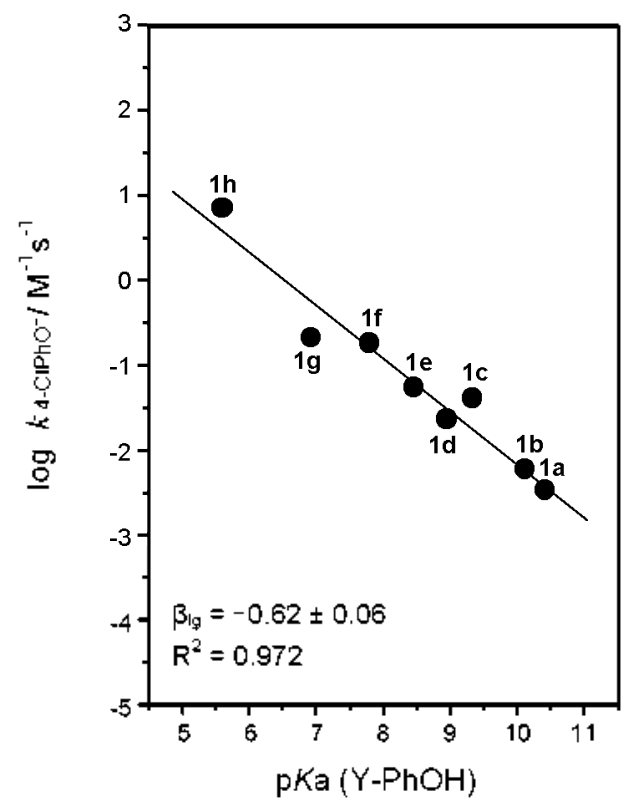

Figure 2. Bronsted-type plot for reactions of 'Y-substituted phenyl benzoates (1a-h) with 4-ClPhO $\mathrm{O}_{1} 80 \mathrm{~mol} \% \mathrm{H}_{-} \mathrm{O} / 20 \mathrm{~mol} \% \mathrm{DMSO}$ at $25.0 \pm 0.1^{\circ} \mathrm{C}$. The identity of points is given in Table 2 .

through a concerted mechanism. ${ }^{8.1:-20}$ However. one cannot obtain conclusive information on mechanism for the current reactions since the plots exhibit many scattered points.

To get more conclusive information on the reaction mechanism, Hammett plots have been constnicted using $\sigma^{\circ}$ and $\sigma^{-}$constants in Figures $3 \mathrm{~A}$ and $3 \mathrm{~B}$. One might expect that $\sigma^{\circ}$ constants would result in a better Hammett correlation than $\sigma^{-}$, if the leaving group departure is not advanced at RDS. In contrast. $\sigma^{-}$constants would give a better correlation than $\sigma^{\circ}$, if the leaving group departure occurs in RDS either in a stepwise mechanism or in a concerted pathway. This is because a partial negative charge, which can be delocalized on the substituent $Y$ through resonance. would develop on the oxygen atom of the leaving aryloxide when the leaving group departure occurs in RDS. As shown in Figures 3A and 3B, $\sigma^{-}$constants result in a slightly better Hammett correlation than $\sigma^{\circ}$ constants. but both plots exhibit highly scattered points. Thus. these Hammett plots cannot provide definitive information on reaction mechanism.

We have recently shown that deduction of reaction mechanism based just on a linear or nonlinear Hanmett plot can be misleading for reactions of 2.4-dinitropheny l X-substituted benzoates and related compounds with amines as well as with anionic nucleophiles such as $\mathrm{OH}^{-}, \mathrm{CN}$. and $\mathrm{N}_{3}^{-} .14 .21 .2=$ Instead. Yukawa-Tsuno plots have been found to be highly effective to elucidate reaction mechanism. ${ }^{5,14,31,22}$ Thus. a Yukawa-Tsuno plot has been constructed using the current kinetic results to deduce reaction mechanism. As shown in Figure 4, the YukawaTsuno plot results in an excellent linear correlation with $\rho_{\mathrm{Y}}=$ 2.26 and $r=0.53$. The $r$ value in the Yukawa-Tsuno equation (eq 2) represents the extent of resonance contribution between the reaction site and substituent $Y^{23}$ Since eq (2) becomes the Hammett equation when $r=0$ or 1 , the fact that $r$ is neither 0 nor $\mathrm{I}$ is consistent with the poor Hammett correlations with $\sigma^{\circ}$
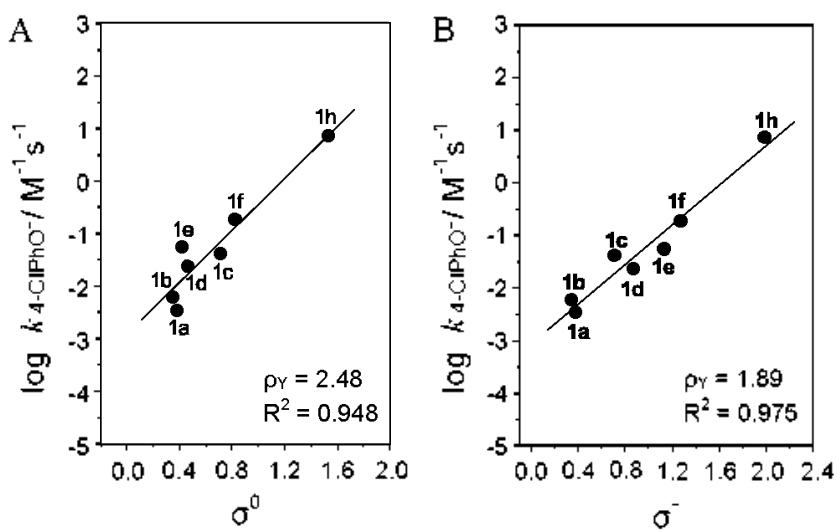

Figure 3. Hammett correlations with $\sigma^{\circ}(\mathrm{A})$ and $\sigma^{-}(\mathrm{B})$ for reactions of Y-substituted phenyl benzoates (1a-h) with $4-\mathrm{ClPhO}^{-}$in $80 \mathrm{~mol} \%$ $\mathrm{H}_{2} \mathrm{O} / 20 \mathrm{~mol} \% \mathrm{DMSO}$ at $25.0 \pm 0.1^{\circ} \mathrm{C}$. The identity of points is given in Table 2.

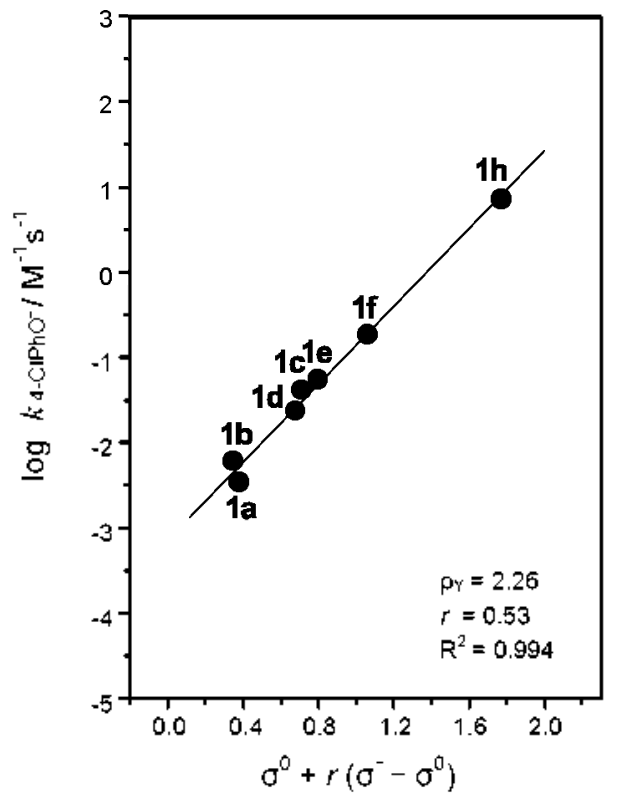

Figure 4. Yukawa-Tsuno plot for reactions of ' Y-substituted phenyl benzoates (1 a-h) with 4-C.PhO in $80 \mathrm{~mol}^{-} \mathrm{H}_{2} \mathrm{O} / 20 \mathrm{~mol} \%$ DMSO at $250 \pm 0.1{ }^{\circ} \mathrm{C}$. The identity of points is given in Table 2 .

or $\sigma^{-}$constants shown in Figure 3

$$
\log k^{Y^{\prime}} / k^{\mathrm{H}}=\rho\left(\sigma^{\circ}+r\left(\sigma^{-}-\sigma^{\prime \prime}\right)\right)
$$

The $r$ value of 0.53 indicates that a negative charge develops partially on the oxygen atom of the leaving aryloxide. Since such a negative charge can be delocalized onto the substituent $Y$ through resonance interaction. two different mechanisms are possible, i.e.. a concerted mechanism and a stepwise process in which expulsion of the leaving group occurs in the RDS. However, one can exclude the latter mechanism as mentioned above. since expulsion of the leaving group is expected to occur rapidly after the RDS on the basis of the fact that $4-\mathrm{ClPhO}^{-}$is more basic and a poorer nucleofuge than all the Y-substituted phenoxides employed in this study. Thus. one can conclude that the reactions of aryl benzoates 1a-h 
with $4-\mathrm{ClPhO}^{-}$proceed through a concerted mechanism, in which bond formation between the nucleophile and the electrophilic center is expected to be more advanced than expulsion of the leaving group.

\section{Summary}

(1) The Bronsted-type plot for reactions of 4-nitrophenyl benzoate with $Z$-substituted phenoxides exhibits an excellent linear correlation with $\beta_{\text {muc }}=0.72$

(2) Reactions of Y-substituted phenyl benzoates (1a-h) with 4-ClPhO ${ }^{-}$result in a linear Bronsted-type plot with $\beta_{\mathrm{lg}}=$ -0.62 , a typical $\beta_{\text {lz }}$ value for a concerted reaction.

(3) Hammett plots correlated with $\sigma^{\circ}$ and $\sigma^{-}$constants exhibit highly scattered points for the reactions of $\mathbf{1 a - h}$ with 4-ClPhO'- while the corresponding Yukawa-Tsuno plot results in an excellent linearity with $\rho_{\mathrm{Y}}=2.26$ and $r=0.53$. indicating that expulsion of the leaving group occurs at the RDS

(4) A stepwise mechanism with leaving group departure being the RDS is excluded since the nucleoplile is more basic and a poorer nucleofuge than the leaving Y-substituted phenoxides

(5) The current reaction proceeds through a concerted mechanism, in which bond formation is expected to be more advanced than expulsion of the leaving group on the basis of the magnitude of $\beta_{\text {uuc }}$ and $\beta_{\mathrm{g}}$ values.

\section{Experimental Section}

Materials. Y-Substituted phenyl benzoates (1a-h) were readily prepared from the reactions of Y-substituted phenol and benzoyl chloride in anlydrous ether in the presence of triethylamine. Their purity was checked by their melting points and ${ }^{\mathrm{H}} \mathrm{H}$ NMR spectra. Phenols were generally recrystallized before use. DMSO and other chemicals were of the highest quality available. Doubly glass-distilled water was further boiled and cooled under nitrogen just before use.

Kinetics. The kinetic study was performed using a UV-Vis spectrophotometer equipped with a constant temperature circulating bath. The reactions were followed by monitoring the appearance of Y-substituted phenoxide at a fixed wavelength corresponding the maximum absorption. Due to low solubility of substrates la-h in pure water, kinetics were performed in 80 $\mathrm{mol}^{2} \% \mathrm{H}_{2} \mathrm{O} / 20 \mathrm{~mol} \%$ DMSO. Typically, the reaction was initiated by adding $5 \mu \mathrm{L}$ of a $0.02 \mathrm{M}$ of substrate stock solution in $\mathrm{MeCN}$ by a $10 \mu \mathrm{L}$ sy ringe to a $10 \mathrm{~mm}$ UV cell containing $2.50 \mathrm{~mL}$ of the reaction medium and nucleophile. The nucleophile stock solution of $c a .0 .2 \mathrm{M}$ was prepared in $25.0 \mathrm{~mL}$ volumetric flask under nitrogen by adding 2 equiv. of $Z$-substituted phenol to 1 equiv. of standardized $\mathrm{NaOH}$ solution to obtain a self-buffered solution. Transfers of solutions were carried out by means of gas-tight șyringes. All reactions were carried out under pseudo-first-order conditions in which nucleophile concentrations were at least 20 times greater than the substrate concentration.

Product Analysis. Y-Substituted phenoxide was identified as one of the products by comparison of the UV-Vis spectra at the end of the reactions with the authentic samples under the same reaction conditions.

Aclonowledgments. This study was supported by Korea Research Foundation (KRF-2008-313-C00500). S. W. Min and J. A. Seo are also grateful for BK 21 Scholarship.

\section{References}

1. (a) Jencks, W. P. Catalysis in Chentisty and Enzmolog: McGraw-Hill: New York, U. S. A., 1969: p 48()-183. (b) Jencks, W. P. Chem. Soc. Rev: 1981, 10, 345-375. (c) Jencks, W. P.; Gilchrist, M. $J$.Ant. Chent. Soc. 1968, 90, 2622-2637. (d) Gresser, M. T. Tencks, W. P. J. Ant. Chent. Soc. 1977, 99, 6963-6970.

2. (a) Page, M; Williams, A. Orgonic and Bio-orgonic Mechonisms; Longman: Harlow, U. K., 1997: Chapter 7. (b) Williams, A. Adv Phys. Org. Chem. 1992, 27, 1-55. (c) Chrystiuk, E.: Williams, A. J. Am. Chem. Soc. 1987, 109, 3040-3046.

3. (a) Castro, E. A. Chem. Rev: 1999, 99, 3505-3524 (b) Castro, E. A.; Echevarria, G. R.; Opazo, A.; Robert, P. S.; Santos, T. G. $J$. Phys. Oig. Chem 2008, 21, 62-67 (c) Castro, E. A.; Agulayo, R: Bessolo, J.: Santos, J. G. J. Phys. Org. Chem 2006, 19, 555-561. (d) Castro, E. A.; Echevarria, G. R.: Opazo, A.: Robert, P. S.; Santos, T. G. J. Phys. Org. Chem. 2006, 19, 129-135. (e) Castro, E. A.: Aguavo, R.: Bessolo, T.: Santos, J. G. J. Org. Chem. 2005, 70,7788-779 1. (f) Castro, E. A.; Aguayo, R.; Bessolo, . T; Santos, J. G. J. Org. Chem 2005, 70,3530-3536. (g) Castro, E. A.; Vivanco, M.; Agleyo, R.; Santos, T. G. J. Ong. Chem 2004, 69 . 5399-5404. (h) Castro, E. A.; Bessolo, J; Aguavo, R.; Santos, J. G. J. Org. Chent. 2003, 68,8157-8161

4. (a) Sung, D. D.; Koo, I. S.; Yang, K.; Lee, I. Chent. Phis. Lent. 2006, $432,426-430$. (b) Sung, D. D.: Koo, I. S.: Yang, K.: Lee, I. Chem. Phus Letr. 2006, 426, 280-284, (c) Oh, H. K.; Oh, J. Y; Sung. D. D.: Lee, I. J. Oig. Chem 2005, 70, 5624-5629. (d) Oh, H. K.; Park, J. E.; Sung, D. D.; Lee, I. J. Org. Chem. 2004, 69, $3150-3153$

5. (a) Um, I. H.: Park, Y. M.; Fujio, M.; Mishima, M.; Tsuno, Y. J. Oig. Chem. 2007, 72, 4816-4821. (b) Um, I. H.: Hwang. S. T.; Baek, M. H.; Park, E. T. J. Org. Chem. 2006, 71,9191-9197. (c) Um, I. H.; Shir, Y. H.; Han, J. Y; Mishima, M. J. Org. Chen. 2006, 71,7715-7720. (d) Um, I. H.: Lee, J. Y: Fujio, M: Tsuno, Y. Ong. Biomol. Chemt 2006, 4, 2979-2985. (e) Um, I. H.; Lee, J. Y.: Ko, S. H.; Bae, S. K. J. Org. Chem. 2006, 71, 5800-5803. (f) Um, I. H.; Teon, S. E.; Seok, J. A. Chem. Em, J. 2006, 12, $1237-1243$.

6. (a) Williams, A. Acc. Chem. Res. 1989, 22, 387-392. (b) Ba-Saif, S. Luthra, A. K.; Williams, A. J. Ant. Chen. Soc. 1989, 111, 2647-2652. (c) Ba-Saif, S.: Luthra, A. K.: Williams, A. J. Am. Chem. Soc. 1987, 109.6362-6368.

7. (a) Buncel, E.; Um, I. H.; Hoz, S. J. Am. Chem. Soc. 1989, 111 , 971-975. (b) Um, I. H; Hwang, S. J.; Buncel, E. J. Org. Chem. 2006, 71,915-920.

8. (a) Um, I. H.; Han, J. Y.: Hwang, S. I. Chem. Em: J. 2008, 14, 7324-7330. (b) Um, I. H.; Park, J. E.: Shin, Y. H. Org. Biomol. Chem. 2007, 5, 3539-3543

9. (a) Tencks, W. P. Chent Rev: 1985, 85,511-527. (b) Grunwald, E. J. Am. Chem. Soc. 1985, 107, 125-133. (c) Grunwald, E. J. Am. Chen. Soc. $1985,107,4710-4715$.

10. (a) Williams, A. Free Energy Relationships in Organic and Bio-Oiganic Chemistry. Royal Society of Chemistry: Cambridge, U. K. 2003; p 297. (b) Leffler, T. E.; Grunwald, E. Extrothemodrnantic Free Energy Relationships, Rates and Equilibria of Organic Reactions; Wiley: New York, U. S. A., 1963; Chapter 7.

11. (a) Jencks, W. P. Catalysis in Chemistn and Enzmolog,; McGraw-Hill: New York, U. S. A., 1969; p 193-199. (b) Anslyn. E. V.: Dougherty, D. A. Modem Plnsical Organic Chemism; 
University Science Books: Sausalito, Califonia, U. S. A., 2006; $\mathrm{p}+10$.

12. (a) Ul Hoque, M. E.: Dev, S.; Guha, A. K.: Kim, C. K.: Lee, B. S.; Lee, H. W. J. Org. Chem 2007, 72,5493-5499 (b) Guha, A. K.: Lee, H. W.: Lee, I. J. Org. (hem. 2000, 65, 12-15. (c) Guha, A. K.: Lee, H. W.: Lee, I. J. Chem. Soc., Perhin Trans. 2 1999, $765-770$.

13. (a) Buncel, E.; Albright, K. G.; Onvido, I. Org. Biontol. Chent. 2004. 2, 601-610. (b) Cook, R. D.: Ralhal-Arabi, L. Tetrahedron Lett. 1985, 26, 3147-3150. (c) Cook, R. D.: Daouk, W. A.: Hajj, A. N.: Kabbani. A.: Kurku. A.: Samaha, M: Shavbant, F.: Tanielianm, O. V. Can. J. Chem. 1986, 64, 213-219. (d) Haake, P: McCov, D. R.; Okamura, W.; Alpha, S. R: Wong. S. Y: Tyssee, D. A.: McNeal, J. P.: Cook, R. D. Tetrahedron Lett. 1968, 9 , 5243-5246. (e) Wallerberg, G.; Haake, P. J. Org. Chem. 1981, $-16,43-46$.

14. (a) Um, I. H.: Han, T. Y.; Shin, Y. H. J. Org. Chem 2009, 7t, 3073-3078. (b) Im, L. R.; Park, Y. M.; Um, I. H. Bull Korean Chem. Soc. 2008, 29, 2477-2481

15. (a) Carrol, F. A. Perspectives in Simuctures and Mechonism in Organic Chentistry; Brook/Cole: New York, 1998; p 371-380. (b) Lowry. T. H.: Richardson, K. S. Mechanism and Theon in Organic Chemistry, 3rd Ed; Happer Collins Publishers: New
York, 1987: p 143-151.

16. (a) Advances in Linear Free-Energy Relationships; Chapman, N. B., Ed.: Plentum: London. 1972. (b) Techniques of Oiganic Chemistry, Vol. 6, 3rd Ed.; Lewis, E. S., Ed.; Wiley: New York, 1974: Part 1. (c) Techmigues of Ongranic Chentistn. Vol. 6, 4th Ed. Bemasconi, C. F., Ed: Wiley: New York, 1986.

17. Onyido, I:: Swierczek, K.: Plureell, J.: Hengge, A. C. J. Am. Chem. Soc: 2005, 127, 7703-7711.

18. (a) Boume, N.: Chrystiuk, E.: Davis, A. M.; Williams, A. J. Am. Chem. Soc. 1988, 110, 1890-1895 (b) Donglas, K. T.; Williams, A. J. Chem. Soc., Pethin Trans. 2 1976.513-515.

19. Younker, T. M.; Hengge, A. C. J. Org. Chem 2004, 69, 9043-9048.

20. Oh, H. K.; Tin, Y. C.; Sung, D. D.; Lee, I. Org. Biontol. Chem. $2005,3,1240-1244$.

21. (a) Um, I. H.; Han, H. J.: Baek, M. H.; Bae, S. Y. J. Org. Chem. 2004, 69, 6365-6370 (b) Um, I. H.: Kim, K. H.; Park, H. R:; Fujio, M.; Tsuno, Y.J. Org. Chent 2004, 69, 3937-3942. (c) Um, I. H.: Min, J. S.; Lee, H. W. Com. J. Chem. 1999, 77, 659-666.

22. Um, I. H.: Han, H. J.: Ahn, J. A.; Kang, S.: Buncel, E. J. Oig. Chem. 2002, 67, 8475-8480.

23. (a) Tsuno, Y; Fujio, M. Adv: Phy Org. Chent 1999, 32, 267-385. (b) Tsuno, Y: Fujio, M. Chem. Soc. Rev 1996, 25, 129-139. (c) Yulawa, Y.; Tsuno, Y. Bull. Chem. Soc. Jph. 1959, 32, 965-970. 